\title{
SEASONAL VARIATION IN THE DIETARY PREFERENCES OF THE MONTANE VOLE, MICROTUS MONTANUS
}

\author{
AElita J. PINTER $\downarrow$ DEPARTMENT OF BIOLOGICAL SCIENCES \\ UNIVERSITY OF NEW ORLEANS $\downarrow$ NEW ORLEANS \\ NORMAN C. NEGUS $\downarrow$ PATRICIA J. BERGER $\downarrow$ BIOLOGY DEPARTMENT \\ UNIVERSITY OF UTAH $\downarrow$ SALT LAKE CITY
}

\section{$\uparrow \quad$ OBJECTIVES}

Seasonal variation in food selection has been documented in several species on voles (Rothstien and Tamarin 1977, Cole and Batzli 1979, Goldberg et al. 1980) with considerable implications for winter survival and population dynamics. In Microtus montanus a similar link may exist between growth, maturation, longevity, and population dynamics on the one hand and dietary composition on the other (e.g., Pinter and Negus 1965, Berger et al 1981, Pinter 1988, Berger et al. 1992, Negus, Berger and Pinter 1992). Consequently, we undertook a study to investigate, in detail, the utilization of plant resources by the montane vole, Microtus montanus. The objectives of this project are twofold: (1) to identify the plant species that constitute the diet in natural populations of $M$. montanus and (2) to determine seasonal food preferences in relation to the availability of plant species and to the age, sex and cohorts of the montane vole.

\section{$\downarrow$ METHODS}

Two field sites, approximately $160 \mathrm{~km}$ apart, in northwestern Wyoming, were used for this study. One study area is within Grand Teton National Park (GTNP site). The other is located along the upper Green River (GR site), near the boundary of the Bridger-Teton National Forest, Sublette County, Wyoming. Both sites are mesic montane meadows at elevations ranging from 2057 to $2134 \mathrm{~m}$. Both sites are quite similar in floristic composition, consisting of a mixture of grasses, sedges, and forbs.

Voles were livetrapped at both sites in spring (May), summer (July-August) and fall (October-November). Winter trapping (monthly sampling, November-March) was accomplished only at the GR site since winter trapping necessitates the use of 5 gallon plastic buckets with tall marker poles and flags. These buckets and poles were established in the late fall before permanent winter snow cover had arrived. Since these structures are highly visible from considerable distances, they would be quite undesirable at sites within Grand Teton National Park. However, we are confident that the winter data can be extrapolated from the GR site to the GTNP site since the two areas have very similar floristic composition and cohort dynamics (Negus, Berger and Pinter, 1992). Initial processing of GTNP field samples was carried out at the UW-NPS Research Center laboratory. Livetrapped animals were sacrificed, and stomach and fecal samples collected. Several slides were prepared from each plant collected. Microscopic identification of plants from stomach and fecal samples and subsequent statistical analysis is being undertaken at the University of Utah, Department of Biology. 


\section{RESULTS}

We had hoped that the 1994 season would be the final year of the study. However, the project is somewhat at the mercy of environmental vagaries and the attendant vole population responses. Our research objectives require moderate to high densities of voles in order to obtain definitive samples. Populations of Microtus montanus had crashed in 1993; unexpectedly, however, the densities in 1994 barely rose above the 1993 levels. This precluded attaining our objectives in 1994: (a) filling in data gaps with respect to cohort differences in food resource utilization and (b) determining the fiber content of specific plants being utilized by voles before and after they make their dramatic seasonal switch to alternative food plants. These gaps will be filled in 1995, because in 1995 vole densities should rise significantly above the 1994 levels.

Apparently, relatively few species of monocotyledons form the bulk of the summer dict for the montane vole. We are in the process of determining the relative importance of these species in the diet. The following species appear to be extensively utilized whenever they are available as plants: Stipa sp., Agropyron cristatum, Poa pratensis, Phelum pratense, Dactylis glomerata, Deschampsia caespitosa, Carex sp., Trisetum wolfii, Festuca sp. Other species that are utilized at lower frequency include the following: Agropyron intermedium, Echinochloa colonum, Hordeum jubatum, Alopecurus sp. With few exceptions, as grasses and sedges approach vegetative maturity just prior to flowering, their use of food resources by montane voles decreases. Doubtless this is due, in part, to the increasingly ligneous nature of the stems as flowering and fruiting is approached. The time needed to attain vegetative maturity varies among species of plants. Consequently, some plants are being consumed for longer periods of their vegetative growth than others. For example, lignification of stems is relatively slow in Poa pratensis and Festuca pratensis, which perhaps accounts for the fact that these grasses are preferential food items for many herbivorous mammals. On the other hand, both Dactylis glomerata and Trisetum wolfii are consumed by voles at high frequency while the plants are young. However, the frequency of use decreases rapidly since these plants rather quickly develop ligneous stems.

To date we have collected fecal/cecal samples from $M$. montanus in several habitat types at both the Grand Teton and the Upper Green River sites. The samples were taken from voles of all ages. Currently these samples, as well as plant reference materials, are being processed; a reference library of epidermal plant tissues is now nearing completion. We have also completed plant transects in all study sites to establish the relative abundance of the indigenous plant species.

\section{CONCLUSIONS}

We have observed that voles apparently select food plants based on the growth stage of the plant. These findings now mandate that all growth stages of food plants must be recorded throughout their growing season. These data must then be correlated with the consumption of such plants by voles.

\section{ACKNOWLEDGEMENTS}

We gratefully acknowledge the availability of the facilities and the help of the staff at the University of Wyoming-National Park Service Research Center without which it would have been impossible to accomplish this work.

\section{Literature Cited}

Berger, P.J., N.C. Negus, A.J. Pinter and T.R. Nagy. 1992. The effect of maternal 6-MBOA on growth and development of offspring in Microtus montanus. Canadian J. Zoology 70:518-522.

Berger, P.J., N.C. Negus, E.H. Sanders, and P.H. Gardner. 1981. Chemical triggering of reproduction in Microtus montanus. Science 214:69-70. 
Cole, F.R., and G.O. Batzli. 1979. Nutrition and population dynamics of the prairic vole, Microtus ochrogaster, in central Illinois. J. Anim. Ecol., 48:455-470.

Goldberg, M., N.R. Tabroff, and R.H. Tamarin. 1980. Nutrient variation in beach grass in relation to beach vole feeding. Ecology 61:1029-1033.

Negus, N.C., P.J. Berger, and A.J. Pinter. 1992. Phenotypic plasticity of the montane vole, Microtus montanus in unpredictable environments. Can. J. Zool. 70:2121-2124.
Pinter, A.J. 1988. Multiannual fluctuations in precipitation and population dynamics of the montane vole, Microtus monatnus. Canadian J. Zool. 66:2128-2132.

Pinter, A.J. and N.C. Negus. 1965. Effects of nutrition and photoperiod on reproductive physiology of Microtus montanus. Amer. J. Physiol. 208:633-638.

Rothstein, B. and R.H. Tamarin. 1977. Feeding behavior of the insular beach vole, Microtus breweri. J. Mammal. 58:84-85. 